\title{
A "Primeira Versão" da Teoria da Crise de Marx: a queda da massa de mais-valia social e o limite interno absoluto do capital ${ }^{\star}$
}

\author{
Nuno Miguel Cardoso Machado ${ }^{1}$
}

\begin{abstract}
Resumo
A teoria da crise de Marx é normalmente associada à lei da queda tendencial da taxa de lucro exposta no Livro Terceiro de $O$ Capital. Segundo Marx, a subida da composição orgânica do capital - o fato de o capital variável crescer em termos absolutos, mas decrescer em termos relativos devido à subida mais rápida do capital constante - origina uma queda da taxa geral de lucro que coloca em xeque a reprodução do capital. Neste artigo será defendido que: i) existe uma "primeira versão" da teoria da crise Marxiana, esboçada sobretudo nos Grundrisse, que atribui a crise secular da economia capitalista à eliminação absoluta do trabalho vivo e, portanto, à queda da massa de mais-valia produzida socialmente; ii) apenas esta "primeira versão" da teoria da crise permite deduzir o limite interno absoluto do capital de forma consistente.
\end{abstract}

\section{Palavras-Chave}

Marx. Crise. Mais-valia. Lucro. Trabalho.

\begin{abstract}
Marx's theory of crisis is usually associated with the law of the tendential fall in the rate of profit presented in volume three of Capital. According to Marx, the rising organic composition of capital - the fact that variable capital grows in absolute terms, but falls relatively because of the faster growth of constant capital - results in the fall of the general rate of profit, which undermines the reproduction of capital. In this article I will argue that: i) there is a "first version" of Marx's theory of crisis, outlined especially in the Grundrisse, which ascribes the secular crisis of the capitalist economy to the absolute decline of living labour and, therefore, to the falling mass of socially produced surplus-value; ii) only this "first version" of the theory of crisis allows the absolute internal limit of capital to be deduced consistently.
\end{abstract}

\section{Keywords}

Marx. Crisis. Surplus-value. Profit. Labour.

\section{JEL Classification}

B14. B24. B31.

- O autor agradece o apoio financeiro concedido pela Universidade de Lisboa, no âmbito de uma Bolsa de Doutoramento.

1 Doutorando - Universidade de Lisboa - Insituto Superior de Economia e Gestão (ISEG)

SOCIUS (Centro de Investigação em Sociologia Econômica e das Organizações)

Endereço: Rua Miguel Lupi, 20 - Lisboa - Portugal - CEP: 1249-078

E-mail: nunomachado@iseg.ulisboa.pt - https://orcid.org/0000-0002-7050-4576

Recebido: 10/04/2017. aceite: 17/08/2017.

(c) (i) (\$) Esta obra está licenciada com uma Licença Creative Commons Atribuição-Não Comercial 4.0 Internacional. 
[A] tendência histórica da nossa era é a crise fatal da produção capitalista, (...) uma crise que terminará com a sua destruição (Marx 1989c, 357).

\section{Introdução}

Nas últimas décadas, tornou-se hegemônica, no campo Marxista, a visão de que a teoria da crise de Marx refere-se à chamada lei da queda tendencial da taxa de lucro (Clarke 1994, 63), apresentada no Livro Terceiro de $\mathrm{O}$ Capital. A crise refere-se, aí, à diminuição relativa do capital variável no decurso da evolução histórica do modo de produção capitalista. $\mathrm{Na}$ perspetiva de Marx, o capital variável aumentaria continuamente em termos absolutos, mas numa proporção decrescente face ao aumento mais rápido do capital constante, o que provocaria uma diminuição inelutável da taxa média de lucro, apesar da existência de algumas causas contrariantes. A massa de mais-valia social (igual à massa de lucro) cresceria indefinidamente.

Todavia, é possível identificar a existência de uma versão anterior da teoria da crise Marxiana (cf. Botelho 2009, 72; Jappe 2006, 131-148; Silva Júnior $2010,136)$, que tem sido frequentemente escamoteada na literatura. Isso talvez se deva ao fato de esta teoria não ter sido alvo de uma exposição sistemática por parte de Marx, encontrando-se dispersa por diversos trechos, sobretudo dos Grundrisse, mas também do Manuscrito Econômico de 1861-63 e do Livro Primeiro de O Capital. Aquela que designarei por "primeira versão" da teoria da crise postula a diminuição absoluta do trabalho vivo envolvido no processo de produção imediato e a consequente queda da massa de mais-valia social.

Neste artigo procurar-se-á, através de uma análise imanente, exegética, apresentar evidências textuais que comprovam a existência de uma "primeira versão" da teoria da crise nas obras de Marx, referente: i) aos limites sociais e, em última instância, fisiológicos da mais-valia absoluta; ii) às dificuldades de produção de mais-valia relativa ligadas à trajetória histórica peculiar do processo de acumulação do capital; iii) à divergência crescente entre riqueza material e valor econômico; iv) ao decréscimo absoluto da força de trabalho empregada; v) ao aumento relativo do trabalho improdu- 
tivo. É evidente que "mesmo uma reconstrução imanente não pode deixar de ser interpretativa" (Reuten 2004, 118).

Em seguida, esta "primeira versão" da teoria da crise será comparada com a lei da queda tendencial da taxa de lucro. A tese central defendida no artigo enuncia que não é possível deduzir um limite interno absoluto da acumulação de capital a partir da queda da taxa de lucro. O colapso da economia capitalista apenas pode ser deduzido teoricamente da queda da massa de mais-valia criada socialmente.

Estou perfeitamente consciente que o "colapso do capitalismo" é uma ideia "altamente controversa" (Ramtin 1991, x), mas a sua centralidade no pensamento de Marx é inquestionável. Tal como refere Ramtin, a teoria de Marx não procura apenas perceber "como o capitalismo funciona" (Ramtin 1991, 179, itálico no original); ela "revela-nos as contradições que conduzem o sistema [capitalista] à sua própria negação" (Ramtin 1991, 179).

\section{Teorias da Crise Marxistas: breve revisão crítica}

É seguro afirmar que "não é possível encontrar uma teoria da crise abrangente na obra de Marx, mas somente observações dispersas, mais ou menos elaboradas, a partir das quais os autores Marxistas desenvolveram teorias da crise bem distintas" (Heinrich 2012, 171). Segundo Ernest Mandel, "existem três variantes principais de interpretação monocausal da teoria da crise de Marx" (Mandel 1991, 42):

i) A teoria da desproporcionalidade explica a crise através da desproporção, em termos de valor de uso e/ou de valor, entre os vários ramos de negócio que compõem a economia capitalista. Em suma, a crise é atribuída à "anarquia do mercado" (Clarke 1994, 9). Dois dos principais proponentes desta teoria são Rudolf Hilferding (cf. 1981) e Nikolai Bukharin (cf. 1972);

ii) A teoria do subconsumo, predominante desde o final dos anos 30 até ao início dos anos 70 (Clarke 1994, 6-7), explica a crise através do "desfasamento entre o output (ou capacidade produtiva) e o consumo da massa da população (os salários reais ou poder de compra dos trabalhadores)" 
(Mandel 1991, 44), pelo que a causa derradeira da crise é a "sobreprodução de mercadorias no Departamento II" (Mandel 1991, 44). Os principais defensores desta teoria são Rosa Luxemburgo (cf. 2003) - que coloca uma grande ênfase nas dificuldades de realização da mais-valia, no contexto dos esquemas de reprodução do Livro Segundo - e os autores estado-unidenses associados à revista Monthly Review (cf. Baran e Sweezy 1968; Sweezy 1962);

iii) A teoria da sobreacumulação, predominante desde o início da década de 1970 (Clarke 1994, 7), justifica a crise com a queda da taxa de lucro, provocada pelo aumento da composição orgânica do capital, i.e., pela adoção de "tecnologia de produção cada vez mais capital-intensiva" (Clarke 1994, 63). A taxa de lucro é diretamente proporcional à taxa de exploração e inversamente proporcional à composição orgânica do capital (Clarke 1994, 65-66). A teoria da sobreacumulação defende que a evolução "histórica da produção capitalista" vai no sentido de uma "tendência constante para o aumento da composição do capital em termos de valor" (Clarke 1994, 66). Com uma dada taxa de exploração, isto implica a queda da taxa de lucro (Clarke 1994, 66). Neste contexto, o capital variável reduzido, em termos relativos, seria supostamente incapaz de providenciar a mais-valia exigida para valorizar um capital de grandeza acrescida. Os principais defensores desta teoria são Henryk Grossman (cf. 1992) e Paul Mattick (cf. 1981).

As teorias da crise distinguem-se, ainda, quanto ao horizonte temporal da sua análise (Mandel 1991, 33). Tradicionalmente, a teoria da desproporcionalidade versa apenas sobre os desequilíbrios que explicam o ciclo econômico (Clarke 1994, 38). Quanto às teorias do subconsumo e da sobreacumulação, ambas foram utilizadas para analisar tanto as crises periódicas como a trajetória secular da acumulação de capital.

Hoje em dia, porém, os autores Marxistas mais consagrados entendem a crise como um fenômeno exclusivamente cíclico. Andrew Kliman (cf. 2012) e Michael Roberts (cf. 2016) atribuem as crises recorrentes à queda temporária da taxa de lucro, enquanto David Harvey (cf. 2010) explica o padrão cíclico capitalista com recurso a uma hibridização da teoria subconsumista com a teoria da sobreacumulação. Em síntese, a crise não é apreendida, neste autores, como uma "barreira absoluta" à expansão do capital, mas como "uma barreira repetidamente posta e superada no curso irregular e propício a crises do desenvolvimento capitalista" (Shortall 1994, 391). 
Deve notar-se que as teorias da desproporcionalidade, do subconsumo e da sobreacumulação encontram algum tipo de apoio textual em afirmações dispersas de Marx, sobretudo no Livro Terceiro de O Capital. Importa realçar, contudo, que tanto a teoria da desproporcionalidade como a teoria do subconsumo cingem-se à esfera da circulação: a crise tem origem nos problemas de realização do valor (e da mais-valia) previamente produzido. Paul Mattick salienta as insuficiências destas teorias:

[N] a medida em que o processo de reprodução depende da acumulação de capital, e portanto da massa de mais-valia que torna a acumulação possível, é no interior da esfera da produção que se encontram os fatores decisivos (embora não os únicos fatores) para a transformação da possibilidade de crise numa crise real (Mattick 1981, 60).

Em particular, julgo ser fundamental rebater o subconsumismo que, apesar do seu caráter aparentemente intuitivo e do seu elevado número de adeptos (sobretudo entre aqueles que procuram mesclar as teorias de Marx e de Keynes), contraria claramente o etos da crítica da economia política:

O poder de consumo limitado da massa da população seria de fato uma barreira à acumulação sustentada de capital se o consumo fosse a força motriz da acumulação. Todavia, para o Marxismo a força motriz da acumulação capitalista não é o consumo mas o lucro. (...) O capitalista não investe por causa de uma procura adicional já existente, o capitalista investe de modo a reduzir os seus custos de produção e a aumentar a sua taxa de lucro, portanto, para ganhar uma fatia maior do mercado existente à custa dos seus concorrentes. Porém, o resultado deste investimento é o aumento da procura total por força de trabalho e por meios de produção (...). Desde que o excedente apropriado pelos capitalistas seja consumido ou reinvestido por eles (ou emprestado a outros que o reinvestem), as despesas de consumo e de investimento dos capitalistas providenciarão a procura acrescida correspondente à oferta acrescida de produtos. O poder de consumo limitado da massa da população é tão-somente o outro lado da massa de lucro crescente 
apropriada pelos capitalistas. (...) [N]ão há nenhuma razão para que a massa de lucro em ascensão não seja reinvestida produtivamente, sendo que quanto maior for a taxa de lucro tanto mais rápida será a acumulação de capital. Na medida em que este reinvestimento toma lugar, não há nenhuma razão para que a acumulação de capital seja entravada pelos limites do mercado (...). O poder de consumo limitado da massa da população não é uma barreira à acumulação continuada porque a força motriz da acumulação capitalista não é o consumo mas a produção e a apropriação de mais-valia (Clarke 1994, 33-34).

Segundo Marx, o valor do produto anual decompõe-se em capital constante + capital variável + mais-valia. Naturalmente que a classe trabalhadora, no seu conjunto, apenas pode realizar a parcela correspondente ao valor da sua força de trabalho. Se o raciocínio equivocado da teoria subconsumista fosse válido, então deveria existir uma situação de subconsumo permanente, pelo que paradoxalmente a questão passaria por explicar como é que a reprodução macrossocial do capital seria possível de todo.

Em suma, conforme salienta Paul Mattick, "a realização da mais-valia não pode ser entendida como principal problema do modo de produção capitalista. (...) [A] origem da crise jaz na insuficiência da produção de mais-valia" $(1981,63)$. Todavia, a própria teoria de Mattick apresenta uma falha crucial: apesar de apreender corretamente o locus da crise na esfera da produção, desloca a sua atenção da massa absoluta para a massa relativa de lucro, i.e., para a queda da taxa de lucro. Segundo Mattick, a massa de lucro, embora maior em termos absolutos, seria supostamente insuficiente para responder às necessidades de expansão ulterior do capital (cf. 1983 , 15). Esta visão é manifestamente incorreta porque, tal como observa Simon Clarke,

os recursos [monetários] disponíveis para o investimento são determinados pela massa de lucro e não pela sua taxa. Mesmo que a taxa de lucro caia, cada capitalista individual apropria-se de uma massa maior de lucro e, portanto, possui os recursos necessários para financiar tanto o seu consumo como o seu reinvestimento $(1994,59)$. 
Ora, conforme será defendido nas páginas seguintes, existe outra leitura possível da teoria da crise de Marx com base na dinâmica de produção e acumulação de capital. Esta teoria aponta a queda absoluta da massa de mais-valia global, resultante da redução absoluta da força de trabalho empregada, como a causa fundamental da crise secular capitalista. O desenvolvimento das forças produtivas materiais entra em contradição insanável com a forma da riqueza burguesa: o valor.

Embora representem uma posição minoritária, vários autores defendem que a chamada $3^{\text {a }}$ Revolução Industrial - associada à tecnologia microeletrônica - impõe uma rutura qualitativa: doravante, o trabalho vivo não vê simplesmente a sua força produtiva aumentar, mas é gradualmente expulso do processo de produção imediato, devindo supérfluo em virtude do desenvolvimento técnico, tecnológico e científico faraônico (cf. Gorz 2010, 21-42 e 119-183; Kurz 2014, 211-320; Lohoff e Trenkle 2014; Ramtin 1991).

\section{A "Primeira Versão" da Teoria da Crise Marxiana}

\subsection{Dos limites da Mais-Valia Absoluta aos Limites da Mais-Valia Relativa}

[Q] uanto mais elevado o desenvolvimento do capital, tanto mais ele aparece como obstáculo da produção (Marx 2011, 340).

Como é sabido, Marx divide a jornada de trabalho em duas parcelas que designa por tempo de trabalho necessário e tempo de trabalho excedente ou mais-trabalho. Durante o primeiro período, os trabalhadores produzem o valor necessário para a reprodução da sua força de trabalho - o seu salário. O segundo período é composto pelo tempo de trabalho excedente durante o qual os trabalhadores produzem um valor excedente - a mais-valia - apropriado pelo capitalista. Se o tempo de trabalho necessário for uma grandeza dada, a mais-valia criada depende inteiramente da duração da jornada de trabalho: quanto mais longa for a jornada, maior será o tempo de mais-trabalho. Marx designa por mais-valia absoluta aquela que se obtém através do prolongamento do horário de trabalho. 
Marx afirma que o limite máximo da jornada de trabalho é "duplamente determinado" (Marx 1996a, 346). Em primeiro lugar, "pela limitação física da força de trabalho", i.e., um indivíduo, ao longo das 24 horas diárias, somente é capaz de despender um dado "quantum de força vital" (Marx 1996a, 346). Os indivíduos precisam igualmente de tempo para repor as suas energias, dormir e satisfazer as suas necessidades vitais (alimentação, etc.). Para além deste limite físico, a jornada de trabalho enfrenta "limites morais" estabelecidos socialmente: "o trabalhador precisa de tempo para satisfazer (...) necessidades espirituais e sociais, cuja extensão e número são determinados pelo nível geral de cultura" (Marx 1996a, 346).

O fato a reter é que a duração absoluta da jornada de trabalho possui "limites intransponíveis" (Marx 1996a, 419) e que, numa dada sociedade, ela é uma grandeza mais ou menos estável, determinada cultural e socialmente. É claro que o capital procurará sempre ultrapassar essas barreiras, especialmente quando confrontado com dificuldades de valorização, mas, em última instância, os limites físicos e biológicos do ser humano são uma barreira intransponível que se imporá mais cedo ou mais tarde. Em suma, a extração de mais-valia absoluta torna-se progressiva e literalmente impossivel.

A mais-valia produzida pode, contudo, ser incrementada sem que a duração da jornada de trabalho sofra qualquer alteração. A denominada mais-valia relativa pode ser extraída de duas maneiras. Em primeiro lugar, através da intensificação do ritmo de trabalho, ou seja, aperfeiçoando a maquinaria, acelerando o seu ritmo de funcionamento e forçando o trabalhador a acompanhá-lo (Marx 1996b, 44-45). Assiste-se, assim, a um "maior dispêndio de trabalho" no mesmo período temporal (Marx 1996b, 42), isto é, a uma "condensação do trabalho" (Marx 1996b, 43). A duração absoluta da jornada de trabalho pode, inclusive, ser reduzida, pois "ganha-se em grau de esforço o que se perde em duração" (Marx 1996b, 43). ${ }^{1}$

No entanto, esta "jornada de trabalho condensada" - mais trabalho-intensiva - também possui limites claramente definidos (Marx 1988, 338): o corpo humano, ao contrário da maquinaria, não é capaz de suportar ritmos

1 É inequívoco que Marx considera a intensificação do ritmo de trabalho no âmbito da mais-valia relativa e não da mais-valia absoluta. No Livro Primeiro de O Capital, o assunto é abordado no Capítulo XIII da Seção IV, justamente intitulada "A Produção da Mais-Valia Relativa" (cf. Marx 1996b, 42-51). O pano de fundo da sua teorização é o desenvolvimento da maquinaria e a redução histórica da jornada de trabalho. Porém, esta conceitualização Marxiana não é consensual e tem sido objeto de algumas críticas (cf. Mavroudeas e Ioannides, 2011). 
de trabalho intensos por períodos muito longos. Atingido um determinado limiar, o aumento ulterior da intensidade do trabalho pressupõe reduções cada vez maiores da duração da jornada de trabalho (Marx 1991, 385).

Segundo Marx, a mais-valia relativa pode ser extraída de uma segunda maneira, típica do capitalismo desenvolvido: através do aumento do tempo de mais-trabalho à custa da redução do tempo de trabalho necessário. Isso implica, na prática, a redução do valor da força de trabalho, conseguida através da redução do valor dos meios de subsistência. Assim, a chave da mais-valia relativa é o aumento da produtividade nos setores que fornecem a cesta de bens adquirida pelos trabalhadores com os seus salários: "Para que diminua o valor da força de trabalho, o aumento da força produtiva tem de atingir ramos industriais cujos produtos determinam o valor da força de trabalho, que, portanto, ou pertençam à esfera dos meios de subsistência costumeiros ou possam substituí-los" (Marx 1996a, 432).

Note-se que a redução do valor da força de trabalho não implica uma deterioração do padrão de vida dos trabalhadores, pois um salário nominal menor permite comprar a mesma massa de valores de uso, ou seja, o salário real mantém-se inalterado. Aliás, o aumento da mais-valia relativa não é incompatível com o aumento do salário real e, para além disso, a subida do salário real e da mais-valia relativa podem inclusivamente ser conjugados com uma redução da duração da jornada de trabalho, como atesta a história dos países capitalistas ocidentais.

Visto que a criação da mais-valia relativa não depende do aumento da força produtiva do trabalho em empresas isoladas, está fora da alçada do capitalista individual reduzir o valor da força de trabalho que emprega. Aquilo que impulsiona o progresso técnico ao nível dos capitais individuais é outro fator, a saber: a apropriação temporária de uma massa de mais-valia extra quando os seus custos de produção são inferiores aos custos de produção médios vigentes no seu ramo de negócio. A concorrência intrassectorial recompensa os capitais inovadores. Desta forma, a redução do valor da força de trabalho é o resultado inadvertido do processo geral de inovação que carateriza o capitalismo - na prossecução da mais-valia suplementar -, sempre que ele abarca os ramos de produção que compõem o Departamento II.

Dadas as barreiras que se colocam à extração de mais-valia absoluta, a mais-valia relativa é a forma por excelência assumida pela mais-valia no 
capitalismo maduro, marcado pela subsunção real do trabalho ao capital. Todavia, como se verá, quanto mais desenvolvido for o modo de produção capitalista, tanto maiores serão as dificuldades que se colocam à criação de mais-valia relativa. Por outras palavras, na ótica de Marx, a mais-valia relativa também possui limites históricos, um aspeto da sua teoria que tem sido frequentemente escamoteado.

Marx escreve nos Grundrisse que podem ser retiradas três grandes conclusões no que toca à mais-valia relativa. Em primeiro lugar, "o aumento da força produtiva só pode aumentar o trabalho excedente (...) à medida que ele diminui a proporção do trabalho necessário em relação ao trabalho excedente" (Marx 2011, 268, itálico no original). Portanto, este aumento da força produtiva tem de ocorrer forçosamente, conforme foi mencionado, nos ramos que produzem meios de subsistência adquiridos pelos trabalhadores com o seu salário.

Em segundo lugar, "o mais-valor do capital não aumenta na mesma proporção que o multiplicador da força produtiva" (Marx 2011, 268), ou seja, "a proporção em que a força produtiva do trabalho aumenta o valor do capital depende da proporção inicial" do trabalho necessário face ao mais-trabalho (Marx 2011, 268): ${ }^{2}$

Se a força produtiva duplica [nos setores que produzem meios de subsistência], (...) o trabalhador precisa trabalhar tão-somente $1 / 2$ do tempo anterior para sacar o preço do trabalho; mas quanto tempo de trabalho ele ainda precisa para tal propósito depende da primeira proporção dada, a saber, do tempo que precisava para tanto antes do aumento da força produtiva. O multiplicador da força produtiva é o divisor dessa fração inicial. Por essa razão, (...) o trabalho excedente não aumenta na mesma proporção numérica que a força produtiva. Se a proporção inicial é $1 / 2$ e a força produtiva duplica, o tempo de trabalho necessário (para o trabalhador) se reduz a $1 / 4$ e o valor excedente só aumenta 1/4 [i.e., passa de 1/2 = 2/ 4 para 3/4]. Se a força produtiva quadruplica, a proporção inicial torna-se $1 / 8$ e o valor [excedente] só cresce $3 / 8$ [i.e., passa de $1 / 2=4 / 8$ para $7 / 8$ ].

${ }^{2}$ Mario Duayer e Nélio Schneider, tradutores da edição portuguesa dos Grundrisse, optaram por utilizar o termo "mais-valor", ao invés de "mais-valia", para traduzir "mehrwert". 
O valor [excedente] jamais pode ser igual ao da jornada de trabalho inteira; ou seja, uma parte determinada da jornada de trabalho sempre tem de ser trocada pelo trabalho objetivado no trabalhador (Marx 2011, 266-267).

Assim, quanto menor for a parcela do trabalho necessário antes do aumento da produtividade, menor será o aumento conseguido na parcela do mais-trabalho. Se, por exemplo, o trabalho necessário já representar somente 2/100 da jornada de trabalho (e o mais-trabalho representar, portanto, 98/100), então uma duplicação da força produtiva do trabalho - nos setores que produzem bens de subsistência - implicará que a proporção do trabalho necessário diminua para $1 / 100$ da jornada de trabalho, enquanto a proporção do mais trabalho aumentará para 99/100 de jornada de trabalho; ou seja, o mais-trabalho aumentará somente $1 \%$ apesar de a força produtiva do trabalho ter aumentado $100 \%$ ?

Finalmente, em terceiro lugar, na sequência do que foi exposto, Marx conclui que a mais-valia relativa possui limites óbvios, pois

quanto maior o valor excedente do capital antes do aumento da força produtiva, quanto maior o quantum pressuposto do trabalho excedente (...), ou quanto menor for já a fração da jornada de trabalho que constitui o equivalente do trabalhador, a fração que expressa o trabalho necessário [i.e., o salário], tanto menor é o crescimento do valor excedente que o capital obtém do aumento da força produtiva. (...) Consequentemente, quanto mais desenvolvido o capital, quanto mais trabalho excedente criou, tanto mais extraordinariamente tem de desenvolver a força produtiva do trabalho para valorizar-se em proporção infima, i.e., para agregar mais-valor - porque o seu limite continua sendo a proporção entre a fração da jornada que expressa o trabalho necessário $e$ a jornada de trabalho total. O capital pode se mover unicamente no interior dessas fronteiras. Quanto menor é a fração que corresponde ao trabalho necessário, quanto maior o trabalho excedente, tanto menos pode qualquer aumento da força produtiva reduzir sensivelmente o trabalho necessário (...). A autovalorização 
do capital devém mais difícil à proporção que ele já está valorizado (...) porque o salário já caiu muito, considerado em relação ao produto do trabalho ou à jornada de trabalho vivo (Marx 2011, 269-270).

Marx volta a salientar esta ideia no Manuscrito Econômico de 1861-63:

Quanto maior for a mais-valia antes do novo aumento da força produtiva, i.e., quanto maior já for a parcela da jornada de trabalho que não é paga, $e$ quanto menor for portanto a parcela da jornada de trabalho que é paga, a fração da jornada de trabalho que constitui o equivalente do trabalhador [o salário], menor será o crescimento da mais-valia que o capital obtém de um novo aumento da força produtiva. A mais-valia aumenta, mas numa proporção cada vez menor face ao desenvolvimento das forças produtivas. A barreira [ao aumento da mais-valia relativa] continua a ser o rácio entre a fração da jornada de trabalho que expressa o trabalho necessário $e$ a duração integral da jornada de trabalho. As variações apenas podem ocorrer dentro destes limites. Quanto menor for a fração correspondente ao trabalho necessário, e maior for portanto o mais-trabalho, menor será o rácio em que um aumento da força produtiva diminui o trabalho necessário, uma vez que o denominador da fração será tanto maior. A taxa de auto-valorização do capital cresce portanto mais lentamente à medida que ele já foi valorizado. Isto não acontece, contudo, porque o salário ou o quinhão do trabalhador no produto aumentou, mas porque a fração da jornada de trabalho que representa o trabalho necessário já se tornou extraordinariamente reduzida em relação à jornada de trabalho como um todo (Marx 1988, 251-252).

Pode concluir-se que, à semelhança da mais-valia absoluta, a mais-valia relativa possui limites inultrapassáveis. A acumulação de capital é um processo dinâmico que obedece a uma lógica própria: a mais-valia criada tem 
de aumentar incessantemente sob pena de o sistema entrar em colapso. ${ }^{3}$ Ora, quanto mais elevado for o estádio de desenvolvimento atingido pelo modo de produção capitalista, assente no constante revolucionamento das forças produtivas, ${ }^{4}$ menor será obrigatoriamente a parcela do trabalho necessário de cada jornada de trabalho individual, que acabará por representar uma fração infinitesimal. ${ }^{5}$ Desta forma, os aumentos ulteriores da força produtiva do trabalho provocam somente incrementos cada vez mais homeopáticos na parcela do mais-trabalho.

O nosso raciocínio conduziu-nos, pois, ao seguinte resultado: no capitalismo maduro, a mais-valia - tanto absoluta, como relativa - fornecida, em média, por cada trabalhador já não é passível de ser aumentada durante muito mais tempo. Todavia, para determinar a massa de mais-valia é necessário aferir, adicionalmente, "o número de trabalhadores ocupados simultaneamente" (Rosdolsky 2001, 210), porquanto "a massa de mais-valia produzida é (...) igual à mais-valia que a jornada de trabalho do trabalhador individual fornece, multiplicada pelo número de trabalhadores empregados" (Marx 1996a, 417). Os itens 3.2 e 3.3 revelarão que a grandeza da força de trabalho empregada não é arbitrária, sendo regulada pelo tempo de trabalho socialmente necessário, isto é, pelo padrão objetivo de produtividade disseminado pela concorrência entre os muitos capitais. O desenvolvimento tecnológico e científico redunda na redução do tempo de trabalho socialmente necessário e, dessa forma, na contração do contingente de trabalhadores empregados.

3 "A produção pelo capital sempre começa, portanto, no nível em que certa massa da riqueza social já está concentrada" (Marx 201 1, 489); "o capital, como representante da forma universal da riqueza - do dinheiro -, é o impulso ilimitado e desmedido de transpor seus próprios limites. Cada limite é e tem de ser obstáculo para ele. Caso contrário, deixaria de ser capital - o dinheiro que se produz a si mesmo. (...) Se o capital cresce de 100 para 1000, o 1000 é agora o ponto de partida de onde o aumento tem de se dar; a decuplicação de $1000 \%$ não conta para nada (...). O que aparecia como mais-valor, aparece agora como simples pressuposto" (Marx 2011, 264, itálico no original).

4 "Não restam dúvidas de que, qualquer que tenha sido a forma e o papel das forças produtivas nas sociedades pré e não-capitalistas, é somente no capitalismo que existe o imperativo sem paralelo de um sistema social assente no desenvolvimento sistemático e contínuo das forças produtivas" (Ramtin 1991, 187, itálico no original).

5 Note-se, porém, que o tempo de trabalho necessário nunca pode ser reduzido a 0: "A jornada de trabalho total é um limite que o mais-trabalho nunca consegue alcançar, não importa quão significativa seja a redução do trabalho necessário. (...) [S] e este último se tornar 0, o mais-trabalho também será 0, porquanto ele é apenas uma função do trabalho necessário" (Marx 1994, 79). De modo análogo, Marx escreve nos Grundrisse que se "o tempo de trabalho necessário ficasse $=0$, i.e., se (...) a produção pudesse ocorrer sem qualquer trabalho, não existiria nem valor, nem capital, nem criação de valor" (Marx 2011, 445, itálico no original). 
3.2. Divergência entre valor e riqueza material

A sociedade burguesa, (...) que conjurou gigantescos meios de produção e de troca, assemelha-se ao feiticeiro que já não pode controlar os poderes infernais que invocou. (...) O sistema burguês tornou-se demasiado estreito para conter as riquezas criadas em seu seio (Marx e Engels 2007, 45).

No Livro Primeiro de O Capital Marx traça uma distinção fundamental entre riqueza material e valor:

Um quantum maior de valor de uso representa em si e para si maior riqueza material, dois casacos mais que um. Com dois casacos podem-se vestir duas pessoas, com um casaco, somente uma pessoa etc. Entretanto, à crescente massa de riqueza material pode corresponder um decréscimo simultâneo da grandeza de valor. Esse movimento contraditório origina-se do duplo caráter do trabalho. (...) O trabalho util torna-se, portanto, uma fonte mais rica ou mais pobre de produtos, em proporção direta ao aumento ou à queda de sua força produtiva. Ao contrário, uma mudança da força produtiva não afeta, em si e para si, de modo algum o trabalho representado no valor. (...) O mesmo trabalho proporciona, (...) nos mesmos espaços de tempo, sempre a mesma grandeza de valor, qualquer que seja a mudança da força produtiva. Mas ele fornece, no mesmo espaço de tempo, quantidades diferentes de valores de uso; mais, quando a força produtiva sobe, e menos, quando ela cai. A mesma variação da força produtiva, a qual aumenta a fecundidade do trabalho e, portanto, a massa de valores de uso por ela fornecida, diminui, assim, a grandeza de valor dessa massa global aumentada, quando ela encurta a soma do tempo de trabalho [socialmente] necessário à sua produção (Marx 1996a, 175). 
Marx expressa uma ideia similar nos Manuscrito Econômico de 1861-63:

Em resultado do aumento da produtividade do trabalho, a quantidade de produtos [criada no mesmo período de tempo] aumenta. Esta quantidade total aumentada (...) encerra o mesmo valor do que a quantidade total inferior produzida anteriormente. Assim, o valor do produto ou mercadoria individual diminui, mas é multiplicado por um fator maior, constituído pelo número dos produtos. (...) Estamos, portanto, perante um crescimento da riqueza real sob a forma de valores de uso, sem qualquer crescimento do valor (...) ou tempo de trabalho contido neles (Marx 1988, 241).

Marx acrescenta ainda, nos Resultados do Processo de Produção Imediato, que "o resultado do modo de produção capitalista consiste em elevar constantemente a produtividade do trabalho", isto é, "em repartir continuamente (...) o trabalho novo agregado por uma massa maior de produtos", embaratecendo desse modo as mercadorias; contudo, "este embaratecimento (...) não significa, em si e para si, nenhuma modificação (...) na massa de mais-valia produzida" pelo mesmo trabalho (Marx 1975, 133-134, itálico no original).

Estas observações de Marx são de extrema importância. Ao basear-se na revolução contínua das forças produtivas, o modo de produção capitalista cria uma divergência crescente entre valor e riqueza material, contribuindo involuntariamente para o seu próprio colapso. A disseminação da maquinaria, em particular, implica "um aumento desta diferença entre o processo de trabalho e o processo de valorização" (Marx 1988, 325). Analisemos esta questão pormenorizadamente.

De acordo com Marx, existe uma "contradição entre produção e valorização" (Marx 2011, 339); Marx salienta que "o capital, de acordo com seu conceito, é a unidade" dessa contradição (Marx 2011, 339). Este fato tem implicações de longo alcance, pois se não existe um limite "à produção em geral", a "produção fundada no capital" possui limites insuperáveis (Marx 2011, 339). 
Assim, quando é atingido um determinado limiar, o valor surge como um "obstáculo" à criação de riqueza material (Marx 2011, 339). Estamos perante a "limitação da produção de valores de uso pelo valor", ou seja, "a riqueza real tem de adotar uma forma determinada, distinta dela própria e, portanto, forma absolutamente não idêntica a ela, para se tornar objeto da produção" (Marx 2011, 339, itálico no original). Na sociedade capitalista, a riqueza sensivel tem de ser transformada em dinheiro, i.e., adquirir uma forma diferente de si mesma, para que possa ser desfrutada socialmente pelos seres humanos. Isto acontece porque, devido a uma inversão fetichista, o processo de produção concreto é uma mera forma de manifestação do processo de valorização.

Esta contradição entre o conteúdo sensível, material, tangível da riqueza e a sua forma abstrata fetichista - o valor - conduzirá, na perspetiva de Marx, à derrocada inevitável do modo de produção capitalista. O desenvolvimento enorme das forças produtivas torna o valor - e a sua substância, o trabalho abstrato - obsoletos:

O próprio capital é a contradição em processo, [pelo fato] de que que procura reduzir o tempo de trabalho a um mínimo, ao mesmo tempo que, por outro lado, põe o tempo de trabalho como única medida e fonte da riqueza. (...) Por um lado, portanto, ele traz à vida todas as forças da ciência e da natureza, bem como da combinação social e do intercâmbio social, para tornar a criação da riqueza (...) independente do tempo de trabalho nela empregado. Por outro lado, ele quer medir essas gigantescas forças sociais assim criadas pelo tempo de trabalho e encerrá-las nos $l i$ mites requeridos para conservar o valor já criado como valor. As forças produtivas e as relações sociais (...) aparecem somente como meios para o capital (...) poder produzir a partir de seu fundamento acanhado. De fato, porém, elas constituem as condições materiais para fazê-lo voar pelos ares (Marx 2011, 588-589).

A produção capitalista encontra-se "empenhada numa batalha com a ciência (...) e com as próprias forças produtivas que engendra” (Marx 1989c, 349-350). Neste sentido, pode-se afirmar que a divergência crescente entre riqueza (material) e valor constitui o fundamento da "primeira versão" da 
teoria da crise Marxiana. E esta divergência ilustra nada mais do que $a$ progressiva eliminação do trabalho vivo do processo de produção imediato.

\subsection{A Eliminação Absoluta do Trabalho Vivo}

A obsessão peculiar dos economistas políticos em demonstrar que no longo prazo a indústria em larga escala baseada na utilização de maquinaria reabsorve sempre a população redundante é risivel. Primeiro eles querem provar que a maquinaria é boa porque poupa trabalho, e depois que ela é novamente boa porque não poupa qualquer trabalho (Marx 1994, 30).

Por muito grande que seja o progresso técnico, tecnológico e científico, o modo de produção capitalista é simplesmente incapaz de sobreviver sem a exploração massiva de trabalho vivo: o "pressuposto" da produção capitalista - enquanto "produção baseada no valor" - "continua sendo a massa do tempo de trabalho imediato, o quantum de trabalho empregado como o fator decisivo da produção" de mais-valia (Marx 2011, 587, itálico no original). ${ }^{6}$

Segundo Marx, é um perfeito "absurdo" postular que "o capital é capaz de fazer algo do nada, do menos, um mais, de menos tempo de trabalho excedente (...), mais valor excedente, e que, por isso, possui uma fonte mística de criação de valor, independente da apropriação de trabalho alheio" (Marx 2011, 452, itálico no original). Visto que o trabalho é a única fonte de mais-valia, o desenvolvimento estratosférico das forças produtivas promovido pelo capitalismo comporta uma contradição fundamental, porquanto torna gradualmente supérfluo o dispêndio de força de trabalho humana. O progresso técnico-científico abole o trabalho, o fluido vital do capital. A riqueza material já não pode ser aprisionada na forma fetichista do valor.

6 "Se, sob o capitalismo, "a principal força motriz da máquina económica" é a procura do lucro; (...) se o lucro é composto por tempo de trabalho (...); então, deduz-se que o capital vive somente para apropriar-se de tempo de trabalho (...) suplementar. Vive para extrair - e sob a condição de conseguir extrair - tanto tempo de trabalho [excedente, NM] (...) quanto possível (...) (e se não consegui-lo, o capital «morre»). Esta é a razão por que [o capital, NM] não pode de maneira nenhuma abandonar a referência ao tempo de trabalho imediato enquanto medida da sua valorização" (Basso 2003: 200, itálico no original). 
Marx descreve este processo, nos Grundrisse, da seguinte forma:

[À] medida que a grande indústria se desenvolve, a criação da riqueza efetiva passa a depender menos do tempo de trabalho e do quantum de trabalho empregado que do poder dos agentes postos em movimento (...), poder que (..), por sua vez, não tem nenhuma relação com o tempo de trabalho imediato que custa sua produção, mas que depende, ao contrário, do nível geral da ciência e progresso da tecnologia, ou da aplicação dessa ciência à produção. (...) A riqueza efetiva se manifesta (...) na tremenda desproporção entre o tempo de trabalho empregado e seu produto (...). (...) [O] ser humano se relaciona ao processo de produção muito mais como supervisor e regulador. (...) Ele se coloca ao lado do processo de produção, em lugar de ser seu agente principal. Nessa transformação, o que aparece como a grande coluna de sustentação da produção e da riqueza não é (...) o trabalho imediato que o próprio ser humano executa (...), mas a apropriação de sua própria força produtiva geral, sua compreensão e seu domínio da natureza por sua existência como corpo social - em suma, o desenvolvimento do indivíduo social. O roubo de tempo de trabalho alheio, sobre o qual a riqueza atual se baseia, aparece como fundamento miserável em comparação com esse novo fundamento desenvolvido, criado por meio da própria grande indústria. Tão logo o trabalho na sua forma imediata deixa de ser a grande fonte da riqueza, o tempo de trabalho deixa, e tem de deixar, de ser a sua medida e, em consequência, o valor (...) deixa de ser [a medida] do valor de uso. (...) Com isso, desmorona a produção baseada no valor (...), e o próprio processo de produção material imediato é despido da forma da precariedade e contradição (Marx 2011, 587-588, itálico no original).

Marx conclui que, "com o desenvolvimento da grande indústria, (...) o trabalho imediato enquanto tal (...) deixa de ser a base da produção" (Marx 2011, 591, itálico no original). Em consequência, o capital é involuntariamente responsável pela sua "dissolução" (Marx 2011, 583), porque, "em 
determinado ponto, um desenvolvimento das forças produtivas materiais (...) abole o próprio capital" (Marx 2011, 448-449, itálico no original), ao abolir a sua substância - o trabalho abstrato. O modo de produção capitalista é vítima de um "decréscimo não só relativo, mas absoluto, do número de trabalhadores empregados" (Marx 1996b, 79). Jappe observa que, "paradoxalmente, o capitalismo atinge o seu próprio limite em virtude da sua maior força, a saber, a libertação das forças produtivas" (Jappe 2006, 140).

Estas previsões de Marx - escritas perspicazmente nos anos de 1857 e 1858 - parecem ser confirmadas pela evolução da economia capitalista global no pós-2 ${ }^{a}$ Guerra Mundial. Pietro Basso apresenta alguns dados da construtora automóvel Fiat que ilustram, a título de exemplo, o aumento colossal da produtividade material, sobretudo nos últimos 35 anos:

Em 1900, cinquenta empregados (...) produziam 24 automóveis por ano, sensivelmente metade de um automóvel por empregado. Levou trinta e cinco anos até que o limiar de um automóvel por ano por empregado fosse alcançado. Em 1949, o número ainda era apenas de 1,3 automóveis por empregado, mas aumentou para 3,3 em 1955, 5,7 em 1960 e 8,4 em 1970. Em 1980, o número disparou para 19, e em 1993 para 44 (em Mirafiori). Mas apenas três anos mais tarde, já eram produzidos mais de 64 carros por empregado em Melfi. Em termos físicos, o aumento da produtividade do trabalho fabril, desde 1890, foi de 8800 por cento na unidade de Mirafori/1993 e de 12800 por cento na unidade de Melfi/1996. Se a comparação for feita com o ano de 1949, temos um aumento superior a 3400 por cento em Mirafiori e de sensivelmente 5000 por cento em Melfi $(2003,208)$.

A denominada Revolução Microeletrônica - ou $3^{\text {a }}$ Revolução Industrial - confirma o diagnóstico de Marx acerca da falência sistémica do capitalismo:

Esta revolução já não instaura um novo modelo de acumulação: desde o início, a informática torna inúteis - "não rentáveis» - enormes quantidades de trabalho. Diferentemente do que se passou com o fordismo, a informática provoca essa inutilidade a um 
ritmo tal que já não há extensão do mercado que seja capaz de compensar a redução da parte do trabalho contida em cada mercadoria. A informática corta definitivamente o laço entre a produtividade $e$ o dispêndio de trabalho abstrato incarnado no valor (Jappe 2006, 147).

Isto acontece porque a revolução informática e, em especial, a automação, introduz uma rutura histórica no processo de desenvolvimento das forças produtivas (Ramtin 1991, 5). A disseminação da automação tem o potencial de reduzir, pela primeira vez, em termos absolutos o número de trabalhadores empregados pelo capital à escala social (Ramtin 1991, 105). Logo, por muito elevada que seja a taxa de mais-valia, a força de trabalho residual simplesmente não será capaz de fornecer o mesmo tempo de mais-trabalho, o que coloca em xeque a (re)produção capitalista.

Existe, pois, uma "incompatibilidade real (objetiva) entre o sistema tecnológico da automação e as relações de valor (...) que dominam todo o sistema social" capitalista (Ramtin 1991, 5). Por outras palavras, a automação coloca as forças produtivas em contradição com a forma social do valor (Ramtin 1991, 6). A eliminação do trabalho vivo torna virtualmente "impossível (...) a produção de mais-valia" (Jappe 2006, 142), pelo que o único resultado possível é uma "massa de mais-valia continuamente decrescente" (Ramtin 1991, 102). Neste contexto, "o colapso do capitalismo deve ocorrer com a força inevitável de uma lei natural” (Ramtin 1991, 179, itálico no original).

Entretanto, no capitalismo em decomposição, são os seres humanos que sofrem na pele as consequências da obsolescência da força de trabalho de que são portadores. O resultado final da irracionalidade capitalista não é "um exército crescente de proletários, mas sim (...) uma humanidade supérflua" (Jappe 2006, 156, itálico no original), i.e., as "populações inteiras que já não são "úteis» para a lógica da valorização” (Jappe 2006, 156).

\subsection{A Mistificação dos Preços de Produção}




\subsection{A Mistificação dos Preços de Produção}

A questão existencial que, porventura, já terá assolado o leitor é a seguinte: se o capital depende do trabalho, porque é que se esforça, através de todos os meios possíveis, para eliminá-lo? A resposta cabal a esta pergunta exige que se estabeleça uma ponte entre a "primeira versão" da teoria da crise e alguns preceitos teóricos do Livro Terceiro de O Capital. Em particular, os conceitos de preços de produção, concorrência (intrassectorial e intersectorial) e sobrelucro podem proporcionar uma compreensão mais adequada da crise estrutural associada à disseminação da produção automatizada.

A transformação dos valores em preços de produção significa que a mais-valia criada pela força de trabalho de um certo capital e a mais-valia de que esse capital se apropria, sob a forma de lucro médio, não coincidem. Assim, no seio da esfera da circulação, a "lei interna" que rege a produção capitalista torna-se "invisível e incompreensível para os agentes individuais" (Marx 1986b, 278):

[O] processo real de produção, como unidade do processo imediato de produção e do processo de circulação, gera novas configurações, em que cada vez mais se perde o fio da conexão interna, as relações de produção se autonomizam umas em relação às outras $e$ os componentes de valor se ossificam entre si em formas autônomas. (...) A mais-valia, na forma de lucro, já não é referida à parte do capital investida em trabalho, do qual ela se origina, mas à totalidade do capital. A taxa de lucro passa a ser regulada mediante leis próprias (...). Tudo isso oculta (...) a verdadeira natureza da mais-valia e, daí, o verdadeiro mecanismo do capital. Isso acontece ainda mais pela transformação do lucro em lucro médio e dos valores em preços de produção (...). Aqui intervém um complicado processo social, (...) que (...) separa os (...) os lucros médios nas diferentes esferas da produção da exploração real do trabalho (...). Não só parece ser assim, mas aqui (...) o lucro médio de um capital específico é diferente da mais-valia que esse capital extraiu dos trabalhadores empregados por ele. (...) O lucro parece apenas acessoriamente determinado pela exploração imediata do trabalho (Marx 1986b, 278-279). 
Do ponto de vista do capitalista individual, a ligação entre trabalho e valor ou, mais especificamente, entre mais-trabalho e mais-valia (logo, lucro), é completamente escamoteada. A ilusão de que o lucro é independente do dispêndio de trabalho abstrato é reforçada pelo fato de, ao nível do capital individual e setorial, o lucro ser realmente diferente da mais-valia individual e setorial. Que essa relação entre trabalho e mais-valia é restabelecida ao nível macrossocial e determina a grandeza da massa de mais-valia - do bolo total a ser distribuído - é algo que escapa à compreensão tanto dos sujeitos burgueses como dos economistas, pois eles só conhecem o mercado e as relações de troca.

Deste modo,

Economia de trabalho - não apenas do trabalho necessário para fabricar determinado produto, mas também do número dos trabalhadores ocupados - $e$ maior aplicação de trabalho morto (capital constante) aparece, do ponto de vista [estritamente] econômico, como [uma] operação inteiramente acertada e não parece de antemão afetar, de modo algum, a taxa geral de lucro e o lucro médio (Marx 1986a, 132).

Em síntese, embora o mais-trabalho fornecido pela sua própria força de trabalho possa diminuir em termos absolutos, isso não tem imediatamente repercussões negativas no lucro médio auferido por um dado capital, porquanto este depende da massa agregada de mais-trabalho social. Os incentivos à eliminação do trabalho vivo são reforçados pelo funcionamento da concorrência intersectorial e intrassectorial.

A concorrência intersectorial beneficia os capitais com composições orgânicas superiores: "mediante a concorrência do capital e a equalização das taxas de lucro, uma parte da mais-valia criada nos ramos de negócio com baixa composição orgânica do capital é drenada para os ramos com composição orgânica do capital elevada" (Mandel 1971, 161). Isto implica que "os lucros realizados nos ramos com elevada composição-valor do capital serão maiores do que a mais-valia que produziram diretamente; enquanto nos ramos com baixa composição-valor do capital sucede o caso inverso" (Shortall 1994, 376). 
Por sua vez, o funcionamento da concorrência intrassectorial significa que os capitais mais eficientes, i.e., com custos de produção inferiores à média setorial, auferirão um sobrelucro temporário, enquanto as suas técnicas de produção favoráveis não se disseminarem pelos seus concorrentes. Na prática, há uma transferência intrassectorial de mais-valia dos capitais menos eficientes para os capitais mais produtivos. Em suma, são "as empresas com maquinaria mais desenvolvida, aquelas com a maior composição orgânica do capital, que triunfam na concorrência capitalista" (Mandel 1971, 162), apesar de serem aquelas que menos contribuem, paradoxalmente, para a massa de mais-valia social.

Neste contexto, a automação surge como uma opção perfeitamente racional para os capitais individuais maximizarem o seu quinhão de lucro abocanhado: "o tempo de trabalho (...) aparece (...) aos capitais individuais como um mero obstáculo", algo perfeitamente "desnecessário" (Ramtin 1991, 108). Os trabalhadores passam a constituir uma matéria descartável. No limite, um capital individual pode automatizar completamente o seu processo produtivo e, ainda assim, auferir o lucro médio (proporcional à sua grandeza) e um sobrelucro por via dos seus custos reduzidos. Estamos perante um capital improdutivo, ou seja, que não produz qualquer mais-valia, mas, não obstante, participa na sua redistribuição. Conforme salienta Ramtin,

Não existe (...) qualquer mistério envolvido nesta situação, uma vez que tudo aquilo que o nosso capitalista fez foi apropriar-se de uma parcela da massa de mais-valia [social] sem ter contribuído para a mesma. (...) Com efeito, o nosso capitalista deixou de ser um capitalista produtivo. Todavia, ele apenas pode ser um capitalista não-produtivo (...) e (...) auferir um lucro, porque ainda existem capitais produtivos a funcionar dentro do sistema. Os capitais automatizados (...) obtêm um lucro à custa dos capitais produtivos (...) apenas enquanto estes últimos não automatizarem a sua produção. (...) À medida que a automação se generaliza e os capitais individuais automatizados se tornam mais numerosos, a massa de mais-valia produzida torna-se cada vez mais insuficiente para sustentar todos os capitais existentes (1991, 110, itálico no original). 
Por conseguinte, se é verdade que, por um lado, os capitais inovadores em especial aqueles que investem na automação - obtêm um sobrelucro temporário e aumentam a sua taxa de lucro individual, por outro lado, no longo prazo, o resultado da difusão da automação pela economia é a eliminação progressiva do trabalho vivo, o aumento da composição orgânica do capital social e a correspondente diminuição da massa de lucro social e da taxa média de lucro.

[À] medida que nos aproximamos da automação completa, $m$ - que não é uma proporção mas uma massa absoluta - começa a declinar rapidamente em conjunto com $v$, pois o número de trabalhadores assalariados e número total de horas de trabalho [sociais] diminuem acentuadamente. Com efeito, numa economia plenamente automatizada a mais-valia desapareceria de todo (Mandel 1991, 32, itálico no original).

Isto não invalida a racionalidade da conduta dos capitalistas individuais, pois a inovação incessante é, com efeito, a única arma de que dispõem para aumentar o lucro apropriado, ainda que temporariamente (Kliman 2007, 117). Porém, a maximização do interesse particular acaba por ser contraproducente para o interesse geral da classe capitalista. Na prossecução dos seus interesses particulares, a atuação conjunta dos muitos capitais acaba por engendrar inadvertidamente, mais tarde ou mais cedo, o colapso de todo o modo de produção baseado no valor. Estamos confrontados com uma compulsão objetiva, por via da concorrência, para a automação até à morte.

\subsection{A Importância do Conceito de Trabalho (im)produtivo}

A distinção que Marx estabelece entre trabalho produtivo e trabalho improdutivo é crucial para entender a dinâmica da crise descrita anteriormente. Nas palavras de Marx, "a diferença entre trabalho produtivo e trabalho improdutivo é importante com respeito à acumulação, já que só a troca por trabalho produtivo constitui condição da reconversão da mais-valia em capital" (Marx 1975, 103). Portanto, nem todo o trabalho, conforme foi assumido implicitamente nos itens precedentes, produz mais-valia. 
Segundo Marx apenas é produtivo o trabalhador: a) inserido na produção mercantil; b) assalariado; c) cuja força de trabalho é vendida a um capitalista, i.e., trocada por dinheiro como capital; d) empregado na produção e no transporte de bens e nos serviços (com a exceção importante dos serviços comerciais e financeiros, agrupados na categoria dos custos de circulação); e) envolvido diretamente no processo de produção imediato; e que, portanto, f) produz mais-valia através do fornecimento de trabalho excedente.

Deste modo, entre as múltiplas categorias de trabalhadores produtivos encontram-se, por exemplo: operários no sentido amplo do termo, técnicos de vária ordem, especialistas das profissões intelectuais e científicas, gestores, supervisores, diverso pessoal dos serviços (programadores informáticos, artistas, professores do setor privado, empregados da hotelaria, etc.). 


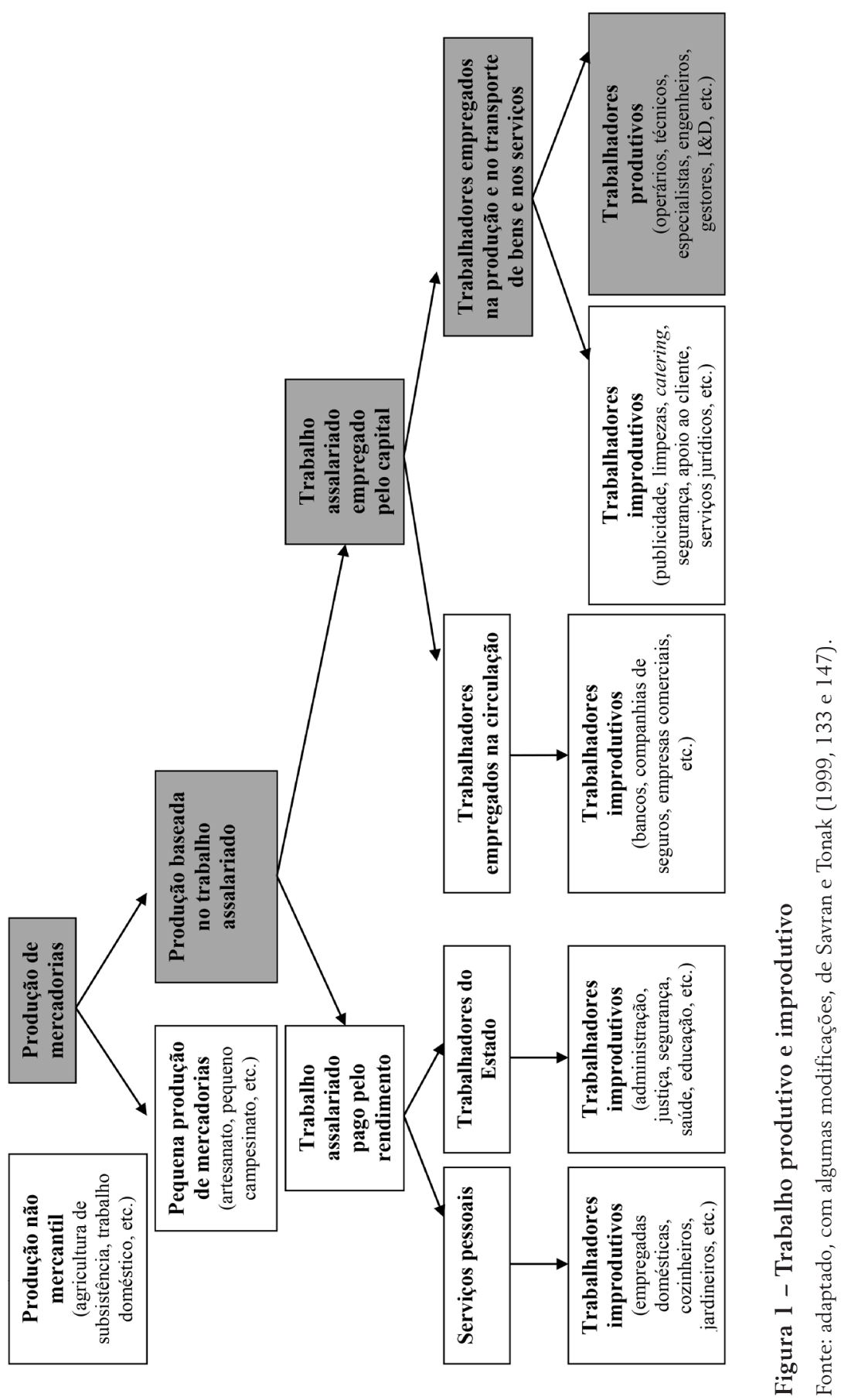


Como é patente na Figura 1, uma parcela considerável da força de trabalho é improdutiva em termos capitalistas, porquanto não produz qualquer mais-valia. ${ }^{7}$ Assim, são improdutivos os trabalhadores:

a) Que fornecem serviços pessoais em troca de rendimento. Incluem-se nesta rubrica empregadas domésticas, jardineiros, motoristas, cozinheiros, etc. pagos com o fundo de consumo do capitalista;

b) Empregados no setor estatal, na medida em que todos estes serviços são financiados por rendimento (impostos ou emissão monetária). Esta rubrica engloba os serviços de administração, justiça e segurança, assim como os serviços sociais do Estado do Bem-Estar (saúde, educação, segurança social, etc.);

c) Empregados na esfera da circulação e envolvidos, portanto, na prestação de serviços financeiros e comerciais. A categoria dos custos de circulação compreende, por um lado, os trabalhadores assalariados da banca, dos seguros, da consultoria, da contabilidade, etc. e, por outro lado, os trabalhadores de todo o tipo de comércio (vendedores, caixas, etc.);

d) Empregados na esfera da produção e transporte de bens, mas que não estão envolvidos diretamente no processo de produção dessas mercadorias. Contam-se nesta categoria de custos improdutivos: os trabalhadores da publicidade, marketing, limpezas, catering, segurança, apoio (mormente telefônico) ao cliente, rececionistas, serviços jurídicos, etc.;

e) Empregados na produção dos serviços elencados em d), quando estes são organizados em ramos de negócio autônomos.

A análise detalhada desta questão extravasa obviamente os limites deste artigo, mas é evidente que, de acordo com a classificação proposta por Marx, uma parte substancial dos novos empregos criados nos últimos 30

7 Um parecerista questiona pertinentemente a classificação, apresentada na Figura 1, do artesanato e da pequena agricultura como "pequena produção de mercadorias". Na sua ótica, estas atividades não constituem realmente uma produção de mercadorias porque não estão subordinadas às relações de produção capitalistas. Assim, creio ser importante precisar o seguinte: é verdade que só no modo de produção capitalista a mercadoria é a forma geral do produto do trabalho, o que envolve determinadas relações de produção, especificamente capitalistas. Todavia, é possível existir uma produção limitada de mercadorias, portanto, de bens que são vendidos no mercado em troca de dinheiro, fora das relações de produção capitalistas. Isso acontecia em várias sociedades pré-capitalistas e continua a ser visível nas margens da sociedade atual. Os pequenos agricultores ou artesãos possuem os seus meios de produção e não empregam trabalhadores assalariados; contudo, vendem no mercado os produtos do seu próprio trabalho. Sobre este assunto, veja-se Jappe (2006, 173-214) e Kurz (2014, 53-62). 
ou 40 anos - sobretudo no chamado setor terciário - são improdutivos. Para além da expulsão massiva do trabalho vivo do processo de produção imediato, tem-se assistido ao aumento relativo concomitante do trabalho improdutivo.

A natureza improdutiva desses postos de trabalho não é percecionada, pois os capitais improdutivos conseguem apropriar-se de um quinhão da mais-valia produzida socialmente sem terem contribuído para ela. Em outros termos, os capitais individuais improdutivos auferem um lucro, mas esse lucro representa uma dedução da massa de mais-valia social criada pela força de trabalho empregada pelos capitais produtivos. Estes amplos setores são alimentados exclusivamente pelo "trabalho" excedente "do trabalhador produtivo" (Marx 1989a, 97). Neste sentido, a proliferação das atividades improdutivas constitui um enorme constrangimento ao processo, em si problemático, de acumulação social do capital.

\subsection{Para uma Sistematização da "Primeira Versão" da Teoria da Crise}

Procuremos, então, sistematizar a "primeira versão" da teoria da crise de Marx. Em termos agregados, do capital social global, apenas é possível aumentar a massa de mais-valia produzida de três formas: i) prolongando a duração da jornada de trabalho individual (mais-valia absoluta); ii) intensificando o ritmo de trabalho ou incrementando a parcela do mais-trabalho à custa da parcela do trabalho necessário da jornada de trabalho individual (mais-valia relativa); iii) aumentando o número de forças de trabalho exploradas simultaneamente. Os itens i) e ii) referem-se à taxa de mais-valia, enquanto o item iii) traduz a grandeza absoluta da população empregada sujeita a uma dada taxa de exploração.

No que se refere à mais-valia absoluta, a jornada de trabalho já atingiu uma duração considerada normal; essa duração é determinada social, cultural e historicamente. Uma das principais conquistas da classe operária, pelo menos nos países ocidentais, foi justamente a redução progressiva da jornada de trabalho. Qualquer tentativa do capital para contrariar este estado de coisas esbarrará em dois limites.

Em primeiro lugar, num limite social, corporizado na resistência ativa dos trabalhadores para defenderem os direitos laborais adquiridos. Em segun- 
do lugar, num limite biológico, porquanto, dado o nível elevado atingido pela intensidade do trabalho - uma das contrapartidas para a redução dos horários de trabalho -, o prolongamento do trabalho conduzirá ao rápido esgotamento físico dos trabalhadores. O efeito previsível do aumento da duração extensiva do trabalho seria uma redução da sua intensidade. Marx é claro: existe um trade-off entre intensidade e extensão do trabalho (cf. Marx 1996b, 42-45).

A mais-valia absoluta é, por assim dizer, o elo mais fraco da produção capitalista: ao contrário da maquinaria, o corpo humano não é capaz de suportar ritmos de trabalho intensos por períodos muito longos. Visto que não é possível prolongar a jornada de trabalho indefinidamente (o trabalhador precisa, pelo menos, de tempo para dormir, alimentar-se, etc.), a sua contribuição decisiva para a acumulação de capital limitou-se, sobretudo, aos estágios iniciais do modo de produção capitalista.

No que diz respeito à mais-valia relativa, esta constitui a forma por excelência da mais-valia no capitalismo maduro. A extração de mais-valia relativa assenta no aumento do tempo de mais-trabalho conseguido através de uma contração do tempo de trabalho necessário à reprodução da força de trabalho. O aumento da força produtiva do trabalho nos ramos que produzem meios de subsistência permite reduzir o valor da força de trabalho e, assim, reduzir a parcela da jornada de trabalho correspondente ao salário do trabalhador. Por sua vez, a parcela do trabalho excedente criador de mais-valia aumenta em termos relativos.

Todavia, 250 anos de progresso técnico, tecnológico e científico contínuo, pautados por três Revoluções Industriais, resultaram na redução do tempo de trabalho necessário a uma grandeza ínfima, praticamente microscópica. Desta maneira - e porque o crescimento do mais-trabalho não é proporcional ao crescimento da produtividade -, são precisos aumentos cada vez mais ciclópicos da força produtiva do trabalho para conseguir aumentos homeopáticos da mais-valia relativa criada.

Marx demonstra que quanto mais elevado for o patamar de desenvolvimento da produção capitalista, tanto mais difícil é a extração da mais-valia relativa. O capital é, pois, vencido pela sua própria lógica: o revolucionamento constante das forças produtivas, crucial para a criação de mais-valia relativa, acaba paradoxalmente por impedir, quando é superado um deter- 
minado limiar, a produção adicional de mais-valia relativa. Já não é possível comprimir mais a parcela do trabalho necessário.

Daquilo que foi exposto resulta que a taxa de mais-valia - ou a mais-valia fornecida por uma dada população empregada - aproxima-se, portanto, dos seus limites históricos. Quando a taxa de exploração atinge um patamar quasi-estacionário, a massa de mais-valia produzida somente poderá crescer se o número de trabalhadores ocupados aumentar em termos absolutos. Porém, o emprego de trabalhadores adicionais não pode ser arbitrário, sendo regulado pelo padrão objetivo de produtividade disseminado pela concorrência através do tempo de trabalho socialmente necessário.

Ora, a concorrência entre os vários capitais obriga-os a embaratecerem as suas mercadorias. Isto é conseguido através do incremento permanente da força produtiva do trabalho. O tempo de trabalho socialmente necessário para produzir uma massa crescente de mercadorias contrai-se continuamente. O desenvolvimento de maquinaria sempre mais eficiente, a aplicação massiva da ciência ao processo produtivo e a difusão da automação significam que a criação de riqueza material depende cada vez menos da quantidade de trabalho despendida.

O valor mercantil torna-se uma quimera à medida que a sua fonte - o trabalho abstrato - seca de modo permanente. Populações inteiras de trabalhadores devêm supérfluas e engrossam as fileiras dos supranumerários da sociedade burguesa. O capitalismo sucumbe ao triunfo autoritário da sua lógica autotélica: o estádio final do desenvolvimento das forças produtivas é a eliminação absoluta de trabalho vivo do processo de produção imediato. Abre-se um abismo entre a capacidade gigantesca de produção de riqueza material e a capacidade minguante de produção de mais-valia, i.e., de aprisionar a riqueza na forma do valor e da mercadoria.

Esta situação é agravada por outro fator: a equalização das taxas de lucro e a formação dos preços de produção implicam que a mais-valia de que cada capital se apropria não coincide com a mais-valia que a sua força de trabalho produziu. Assiste-se a uma transferência intersectorial de mais-valia dos ramos com composição orgânica do capital inferior à composição média social para os ramos com composição orgânica do capital superior à composição média social. Para além disso, existe uma transferência intrassectorial de mais-valia dos capitais menos eficientes para os capitais eficientes de um dado ramo de negócio. 
Visto que o capital individual é capaz de se apropriar de uma massa de mais-valia bastante superior àquela que criou diretamente, surge a ilusão de que a mais-valia já não depende da força de trabalho. O senso comum quotidiano escamoteia completamente que, do ponto de vista da economia no seu conjunto, a massa de valor - logo, de mais-valia - continua a ser determinada exclusivamente pelo dispêndio de trabalho humano.

Esta mistificação conduz o progresso técnico e, em particular, a disseminação da automação aos limites do paroxismo, embora, em última instância, isso acarrete o colapso do modo de produção capitalista. Será correto afirmar que o capital se automatiza até a morte: a maximização da mais-valia apropriada por cada capital inovador é acompanhada pela regressão absoluta da massa de mais-valia produzida socialmente.

Finalmente, a proliferação do trabalho improdutivo em termos capitalistas contribui também para as dificuldades de reprodução macrossocial do capital. A massa de mais-valia social tem de alimentar uma miríade de agentes improdutivos. Apesar de não contribuírem para o bolo comum, os capitais improdutivos abocanham uma fatia do mesmo.

\section{A "Segunda Versão" da Teoria da Crise Marxiana}

No Livro Terceiro, Marx retoma a análise da crise do modo de produção capitalista. Fá-lo através da enunciação da famosa lei da queda tendencial da taxa de lucro, que considera ser a "lei mais importante da economia política" (Marx 1991, 104). Esta "segunda versão" da sua teoria da crise não postula um decréscimo absoluto da força de trabalho global - logo, da massa de mais-valia social -, mas apenas o seu decréscimo relativo. $\mathrm{Na}$ perspetiva de Marx, esta tendência é transversal à economia burguesa e resulta na queda inevitável da taxa geral de lucro.

Marx parte da hipótese simplificadora que o salário e a jornada de trabalho são grandezas dadas, pelo que a taxa de mais-valia é constante e o capital variável funciona como um índice do número de trabalhadores empregados pelo capital social global (Marx 1986a, 163). Neste contexto, "a taxa de lucro depende [exclusivamente] da composição orgânica do capital” 
(Marx 1989b, 60, itálico no original), ou seja, do número de trabalhadores explorados simultaneamente.

Como facilmente se percebe, existe uma relação inversa entre a taxa de lucro e a composição orgânica do capital. A taxa de lucro diminui na medida em que a composição orgânica do capital aumenta e vice-versa. Segundo Marx, a evolução histórica do modo de produção capitalista possui uma tendência inequívoca para o aumento gradual da composição orgânica do capital (Marx 1986a, 164). A subida da composição orgânica não se limita a esferas específicas, mas abarca a totalidade da economia, pelo que se assiste a um aumento da "composição orgânica média do capital global" (Marx 1986a, 163). Marx enuncia a seguinte "lei do modo de produção capitalista":

[C]om seu desenvolvimento, ocorre um decréscimo relativo do capital variável em relação ao capital constante e, com isso, em relação ao capital global posto em movimento. Isso (...) quer dizer que (...) a mesma quantidade de força de trabalho, tornada disponivel por um capital variável de dado (...) valor, devido aos métodos de produção peculiares que se desenvolvem dentro da produção capitalista, põe em movimento, processa e consome produtivamente (...) uma massa sempre crescente de meios de trabalho, maquinaria e capital fixo de toda a espécie, matérias-primas e auxiliares - portanto também um capital constante (...) de valor sempre crescente (1986a, 163-164).

Conforme salienta Brendan Cooney,

Não se trata de uma diminuição [absoluta] do trabalho empregado. A massa absoluta de trabalhadores empregados aumenta à medida que o capital incorpora uma massa maior de seres humanos sob o seu jugo. Mas em termos relativos, em relação ao capital total despendido na produção, a quantidade de trabalho empregado diminui. Marx é de tal modo enfático nesta ideia de uma massa de mais-valia crescente acompanhada pela redução da taxa de lucro, que a repete uma e outra vez $(2011,90)$. 
Para que a diminuição da taxa de lucro, provocada pelo aumento da composição orgânica do capital, não acarrete igualmente uma diminuição da massa de lucro, é preciso que seja cumprida esta condição: o capital global tem de crescer de tal modo que continue a ser empregada pelo menos a mesma grandeza absoluta de força de trabalho (Marx 1986a, 170). Em suma, o aumento do capital global tem de ser pelo menos proporcional à diminuição da taxa média de lucro, para que a massa de lucro não diminua (Marx 1986a, 170).

É evidente que "quanto mais o modo de produção capitalista se desenvolve, uma quantidade cada vez maior de capital se torna necessária para empregar a mesma força de trabalho, e ainda maior para uma força de trabalho crescente" (Marx 1986a, 171). De acordo com Marx, a análise empírica da economia capitalista permite comprovar o funcionamento real do mecanismo compensatório descrito:

O mesmo desenvolvimento da força produtiva do trabalho social, as mesmas leis que se apresentam na queda relativa do capital variável em relação ao capital global (...), por outro lado, (...) se expressa (...) no crescente aumento da força de trabalho global empregada, no crescimento cada vez maior da massa absoluta de mais-valia, e portanto do lucro (Marx 1986a,168-169).

A mesma ideia é expressa em outra passagem:

O número dos trabalhadores empregados pelo capital, portanto a massa absoluta de trabalho posta em movimento por ele, portanto a massa absoluta de mais-trabalho absorvida por ele, (...) a massa absoluta de lucro produzida por ele pode (...) crescer (...) apesar da progressiva queda da taxa de lucro. Isso não apenas pode ser o caso. Tem de ser o caso (...) na base da produção capitalista (Marx 1986a, 167, itálico no original). 
Pode concluir-se que "a queda da taxa de lucro não nasce de uma diminuição absoluta, mas de uma diminuição relativa do componente variável do capital global, de sua diminuição comparada com o componente constante" (Marx 1986a, 167). Ou seja, verifica-se um decréscimo relativo do capital variável porque, embora tanto o capital variável como o capital constante cresçam em termos absolutos, o capital constante cresce mais rapidamente (Marx 1986a, 166).

Marx menciona, ainda, algumas causas contrariantes da lei da queda tendencial da taxa de lucro. Deixando cair as hipóteses simplificadoras iniciais, a taxa de mais-valia e a composição orgânica do capital são os principais fatores que afetam a taxa de lucro. O aumento da taxa de mais-valia e/ou o embaratecimento dos componentes do capital constante atenuam o ritmo da descida da taxa de lucro, mas não são capazes de evitar essa descida. A tese de Marx é que até uma taxa de exploração crescente "se expressa numa taxa geral de lucro em queda contínua" (Marx 1986a, 164), "porque $c / v$ aumenta a um ritmo mais elevado do que $m / v$ " (Smith 2002, 166).

\section{A Impossibilidade de Deduzir o Limite Interno Absoluto da Queda da Taxa de Lucro}

Se a massa de mais-valia social continuar a aumentar ad infinitum, conforme Marx argumenta no Livro Terceiro de O Capital, não se vislumbra como é que o processo de acumulação do capital poderá ser entravado definitivamente. Tom Thomas apreende claramente as antinomias das posições teóricas que tomam a queda tendencial da taxa de lucro como o elemento fulcral da crise sistémica capitalista:

É frequentemente afirmado que este é o fator [a queda da taxa de lucro] essencial da crise, como se a acumulação do capital fosse bloqueada a partir de um nível de taxa de lucro que os capitalistas, e a sua avidez, julgam demasiado baixa. Todavia, este bloqueio da acumulação é menos um caso de subjetividade do que de objetividade. Na medida em que um capital acrescido $\mathrm{C}+\Delta \mathrm{C}$ pode produzir uma massa 
de lucro superior àquela que produzia $\mathrm{C}$, então a acumulação pode prosseguir. Aquilo que é essencial é a massa de lucro, mais do que a sua taxa. Enquanto essa massa aumentar, o capital pode reproduzir-se e expandir-se. Mesmo se ele acumula a uma taxa de 4\% em vez de 8\%, por exemplo, (...) isso não deixa de ser acumulação. Aliás, mesmo com uma taxa mais débil, uma massa grande de capital pode produzir mais lucro do que uma massa pequena, e acumular mais rapidamente. 4\% de 1000 darão 40, enquanto 8\% de 100 darão somente 8. A massa pode crescer quando a taxa cai. Desde que a massa cresça, o capital consegue reproduzir-se. (...) [C]onstatamos que a queda da taxa de lucro não é sinônimo da queda da sua massa e que somente a queda, ou mesmo a simples estagnação, da massa de lucro significa um bloqueio absoluto, generalizado, da acumulação (2004, 40-41, itálico nosso).

É importante ressalvar que a queda da taxa de lucro não é o aspeto crucial para o entendimento da crise. O nó do problema é a impossibilidade de deduzir o limite interno absoluto da acumulação de capital a partir da lei que enuncia a queda tendencial da taxa de lucro. E Marx reconhece esse fato sem qualquer sombra de dúvida: "não se pode deduzir necessariamente a partir desta lei que a acumulação de capital regride ou que a massa absoluta de lucro cai" (Marx 1991, 111, itálico no original). Noutro sítio, Marx é igualmente perentório: "um capital grande com pequena taxa de lucro acumula mais rapidamente do que um capital pequeno com taxa grande" (Marx 1986a, 189).

De acordo com a perspetiva avançada no Livro Terceiro de O Capital, "embora tenham diminuída sua taxa, os lucros aumentam na sua massa à medida que avança a acumulação de capital" (Gorender 1996, 62). A pergunta que se impõe é, naturalmente, a seguinte: se a massa de lucro pode crescer indefinidamente, porque é que o sistema capitalista haverá de colapsar? As conclusões radicais que Marx retira no Livro Terceiro acerca da falência sistémica do capitalismo não são consistentes com as premissas teóricas aventadas. 
Este é justamente o calcanhar de Aquiles da teoria da crise assente exclusivamente na taxa de lucro: visto que nunca é postulada uma queda da massa de mais-valia social, o colapso inevitável do modo de produção capitalista torna-se pura e simplesmente indemonstrável. Conclui-se que o problema dos limites enfrentados pela (re)produção capitalista não pode ser colocado em termos da queda da taxa de lucro, mas, antes, da queda massa de lucro - esse é o seu único obstáculo instransponível, a sua única barreira absoluta.

Mandel adverte justamente que o ponto de não retorno do declínio do modo de produção capitalista é atingido

quando (...) a massa de mais-valia cessa de crescer e começa a declinar - primeiro gradualmente, depois permanentemente. Esta seria obviamente a estocada mais séria infligida ao processo contínuo de acumulação capitalista (...): um nível de mecanização, de semi-automatização - digamos mesmo, de disseminação da automatização plena - de um número crescente de ramos de produção, em que o input total de horas de trabalho produtivo começa a declinar, portanto, em que a produção global de valor decresce. (...) [A] extensão da automatização para além de um certo limiar conduz inevitavelmente, em primeiro lugar, à redução da grandeza total de valor produzida e, seguidamente, à redução da grandeza total de mais-valia produzida (1991, 87, itálico no original).

\section{Conclusão}

A "primeira versão" da teoria da crise de Marx enuncia o colapso do modo de produção capitalista em resultado da diminuição da massa de mais-valia social. Essa diminuição deve-se aos limites históricos da taxa de exploração (mais-valia absoluta e mais-valia relativa) e, acima de tudo, à redução da força de trabalho global empregada mercê da crescente aplicação da maquinaria ao processo de produção imediato. Assiste-se à "dessubstancialização" do valor (Kurz 2004), ao surgimento de um fosso entre a capa- 
cidade colossal de produção de riqueza material e a capacidade declinante de produção de valor e de mais-valia.

Segundo Marx, o capital está enredado numa contradição insuperável. Por um lado, promove um desenvolvimento sem paralelo das forças produtivas, esforçando-se por todos os meios possíveis para eliminar o trabalho do processo de produção imediato, enquanto, por outro lado, quer preservar anacronicamente o tempo de trabalho como medida da riqueza, i.e., a forma fetichista do valor. Esta contradição acabará por desencadear a falência do modo de produção capitalista:

[O] desenvolvimento das forças produtivas suscitado pelo próprio capital em seu desenvolvimento histórico, alcançado certo ponto, suprime, em lugar de pôr, a autovalorização do capital. Para além de certo ponto, o desenvolvimento das forças produtivas devém um obstáculo para o capital (Marx 2011, 627).

Trata-se de "um conflito [insanável] entre o desenvolvimento material da produção e sua forma social" - o valor (Marx 1986b, 315). Nos Grundrisse, Marx é concludente: o único desfecho possível é a "destruição violenta do capital" (Marx 2011, 628). Todavia, visto que desenvolveu as forças produtivas mais poderosas da história da Humanidade, o capital cria simultaneamente "as condições materiais de uma forma de produção superior" (Marx 1986a, 195).

A divergência entre valor e riqueza material atinge o seu clímax com a $3^{\mathrm{a}}$ Revolução Industrial. A microeletrônica e, em especial, a produção automatizada, representa uma rutura qualitativa no desenvolvimento histórico das forças produtivas, porquanto "nega a produção de mais-valia, que é a verdadeira força vital do capital" (Ramtin 1991, 188). Embora a automação seja contraproducente, no longo prazo, para a economia capitalista no seu conjunto, a sua difusão é explicada pelo funcionamento da concorrência:

a) A concorrência intersectorial assegura a equalização das taxas de lucro nos vários ramos de negócio, transformando os valores em preços de produção. Essa equalização promove uma transferência de mais-valia dos ramos com composição orgânica do capital inferior para os ramos com composição orgânica superior à média social. A mais-valia produzida $\mathrm{e}$ 
apropriada por cada capital setorial não coincidem, criando-se a ilusão de que não existe qualquer relação entre trabalho vivo e lucro;

b) A concorrência intrassectorial garante um sobrelucro (temporário) aos capitais com custos de produção inferiores à média setorial. Esse sobrelucro consubstancia-se numa transferência intrassectorial de mais-valia dos capitais com composições orgânicas menores para os capitais com composições orgânicas superiores. A mistificação de que o capital pode reproduzir-se sem explorar o trabalho vivo é reforçada

Neste sentido, na prossecução do seu interesse particular, cada capital contribui involuntariamente para a ruína do sistema capitalista:

A "compulsão cega e não concertada para crescer", sob a pressão constante e intensa da concorrência, é a única autoridade que governa o mundo do capital. (...) É precisamente por "razões ligadas à sua auto- preservação" que cada capital individual deve, em última instância, automatizar-se ou morrer. Na prossecução dos seus próprios interesses individuais, (...) os capitais individuais devem não apenas investir na aplicação da melhor tecnologia disponivel, mas também procurar desenvolver tecnologias cada vez mais avançadas de modo a conseguirem uma vantagem em relação aos seus rivais. É certamente verdade que esse comportamento é contraditório e, em última instância, contraproducente. Mas é contudo inevitável e compulsivo. (...) [N]enhum capital individual pode dar-se ao luxo de não introduzir estas tecnologias. A pressão da concorrência (...) assegurará que a automação é difundida (...) por todo o setor produtivo e para além dele. A automação total significa indubitavelmente o fim do capital. Mas é praticamente impossível congelar o desenvolvimento e a difusão da automação indefinidamente, dada a natureza do sistema. (...) Esta é a contradição (...) que deverá inevitavelmente transformar-se na crise final do capital (Ramtin 1991, 103-104, itálico no original). 
No Livro Terceiro de O Capital, Marx apresenta uma "segunda versão" da teoria da crise que enuncia a diminuição exclusivamente relativa do capital variável e a consequente queda da taxa geral de lucro. Como tive oportunidade de salientar, não é possível deduzir o limite interno absoluto do modo de produção capitalista a partir desta teoria. Enquanto a massa de lucro for aumentando, a reprodução da economia capitalista está assegurada, independentemente do que suceda à taxa média de lucro.

Finalmente note-se que, no Livro Terceiro, Marx ainda está ciente da possibilidade de diminuição absoluta da massa de mais-trabalho defendida pela "primeira versão" da teoria da crise. Porém, descarta essa hipótese, que considera agora ser inverosímil, como denota a sua utilização do condicional neste trecho:

Se (...) o capital tivesse crescido proporcionalmente à população trabalhadora, de tal forma que nem o tempo absoluto de trabalho fornecido por essa população [i.e., a mais-valia absoluta], nem o tempo relativo de mais-trabalho [i.e., a mais-valia relativa] pudessem ser ampliados (...); se, portanto, o capital acrescido só produzisse tanta massa de valor ou até menos do que antes de seu crescimento, então ocorreria uma superprodução absoluta do capital; isto é, o capital acrescido $\mathrm{C}+\Delta \mathrm{C}$ não produziria lucro maior (...) do que o capital $\mathrm{C}$ antes de receber o acréscimo $\Delta \mathrm{C}$ (Marx 1986a, 190).

Não obstante as observações proféticas feitas nos Grundrisse, Marx continuou, nos escritos subsequentes, refém da sua época. Até à data da sua morte, em 1883, Marx testemunhou um modo de produção capitalista em franca ascensão, pelo que uma diminuição absoluta da força de trabalho empregada não passava, aos seus olhos, de uma hipótese mirabolante ou, no melhor dos casos, altamente improvável. Esta terá sido a razão principal que o conduziu ao abandono da "primeira versão" da teoria da crise, esboçada nos anos de 1857 e 1858, e à adoção da "segunda versão" da teoria da crise, elaborada nos anos de 1864 e 1865. Este recuo teórico não apaga, contudo, o brilhantismo das suas primeiras previsões. 


\section{Referências}

Baran, Paul, e Paul Sweezy. 1968. Monopoly Capital: An Essay on the American Economic and Social Order. Nova Iorque: Monthly Review Press.

Basso, Pietro. 2003. Modern Times, Ancient Hours: Working Lives in the Twenty-first Century. Londres: Verso. Botelho, Maurílio Lima. 2009. “Crise da Sociedade do Trabalho: Teorias em Conflito”. Tese (Doutorado), Universidade Federal Rural do Rio de Janeiro.

Bukharin, Nikolai. 1972. "Imperialism and the Accumulation of Capital". In Rosa Luxemburg e Nikolai Bukharin, The Accumulation of Capital: An Anti-Critique/Imperialism and the Accumulation of Capital, 151-270. Nova Iorque: Monthly Review Press.

Clarke, Simon. 1994. Marx's Theory of Crisis. Nova Iorque: St Martin's Press.

Cooney, Brendan. 2011. "Kapital, Volume 3". Disponível em: < https://nunomiguelmachado.files.wordpress. com/2012/01/kapital-3-brendan-cooney-2009-11.pdf> Acesso em: 17 abr. 2016.

Gorender, Jacob. 1996. “Apresentação”. In Karl Marx, O Capital: Crítica da Economia Política. Livro Primeiro. Tomo 1, 5-70. São Paulo: Editora Nova Cultural.

Gorz, André. 2010. Ecologica. Londres: Seagull Books.

Grossman, Henryk. 1992. The Law of Accumulation and Breakdown of the Capitalist System. Being also a Theory of Crises. Londres: Pluto Press.

Harvey, David. 2010. The Enigma of Capital. And the Crises of Capitalism. Londres: Profile Books.

Heinrich, Michael. An Introduction to the Three Volumes of Karl Marx’s Capital. Nova Iorque: Monthly Review Press.

Hilferding, Rudolf. 1981. Finance Capital: A Study of the Latest Phase of Capitalist Development. Londres: Routledge \& Kegan Paul.

Jappe, Anselm. 2006. As Aventuras da Mercadoria: Para uma nova crítica do valor. Lisboa: Antígona.

Kliman, Andrew. 2007. Reclaiming Marx's «Capital»: A Refutation of the Myth of Inconsistency. Plymouth: Lexington Books.

Kliman, Andrew. 2012 The Failure of Capitalist Production: Underlying Causes of the Great Recession. Londres: Pluto Press.

Kurz, Robert. 2004. "A Substância do Capital. O trabalho abstrato como metafísica real social e o limite interno absoluto da valorização. Primeira Parte: A qualidade histórico-social negativa da abstracção «trabalho»." Disponível em: <http://nunomiguelmachado.files.wordpress.com/2012/01/r-kurz.pdf>. Acesso em: 28 out. 2016.

Kurz, Robert. 2014. Dinheiro Sem Valor: Linhas gerais para uma transformação da crítica da economia política. Lisboa: Antígona.

Lohoff, Ernst e Norbert Trenkle. 2014. La grande dévalorisation: Pourquoi la spéculation et la dette de 1'Etat ne sont pas les causes de la crise. Paris: Post Éditions.

Luxemburg, Rosa. 2003. The Accumulation of Capital. Londres: Routledge.

Mandel, Ernest. 1971. Marxist Economic Theory. Volume I. Nova Iorque: Monthly Review Press.

Mandel, Ernest. 1991. “Introduction”. In Karl Marx, Capital: A Critique of Political Economy. Volume III. $2^{\text {a }}$ ed, 9-90. Londres: Penguin Books.

Marx, Karl. 1975. Capítulo Inédito d' O Capital: Resultados do Processo de Produção Imediato. Porto: Publicações Escorpião.

Marx, Karl. 1986a. O Capital: Crítica da Economia Política. Livro Terceiro: O Processo Global da Produção Capitalista. Tomo 1. $2^{\text {a }}$ ed. São Paulo: Editora Nova Cultural.

Marx, Karl. 1986b. O Capital: Crítica da Economia Política. Livro Terceiro: O Processo Global da Produção Capitalista. Tomo 2. $2^{\mathrm{a}}$ ed. São Paulo: Editora Nova Cultural. 
Marx, Karl. 1988. Economic Manuscript of 1861-63. In Karl Marx e Friedrich Engels, Collected Works. Volume 30. Londres: Lawrence \& Wishart, 1988.

Marx, Karl. 1989a. Economic Manuscript of 1861-63 (Continuation). In Karl Marx e Friedrich Engels, Collected Works. Volume 31. Londres: Lawrence \& Wishart

Marx, Karl. 1989b. Economic Manuscript of 1861-63 (Continuation). In Karl Marx e Friedrich Engels, Collected Works. Volume 32. Londres: Lawrence \& Wishart.

Marx, Karl. 1989c. "Drafts to the Letter to Vera Zasulich". In Karl Marx e Friedrich Engels, Collected Works. Volume 24, 346-369. Londres: Lawrence \& Wishart.

Marx, Karl. 1991. Economic Manuscript of 1861-63 (Continuation). In Karl Marx e Friedrich Engels, Collected Works. Volume 33. Londres: Lawrence \& Wishart.

Marx, Karl. 1994. Economic Manuscript of 1861-63 (Conclusion). In Karl Marx e Friedrich Engels, Collected Works. Volume 34. Londres: Lawrence \& Wishart.

Marx, Karl. 1996a. O Capital: Crítica da Economia Política. Livro Primeiro: O Processo de Produção do Capital. Tomo 1. $3^{\text {a }}$ ed. São Paulo: Editora Nova Cultural.

Marx, Karl. 1996b. O Capital: Crítica da Economia Política. Livro Primeiro: O Processo de Produção do Capital. Tomo 2. $3^{\text {a }}$ ed. São Paulo: Editora Nova Cultural.

Marx, Karl. 2011 Grundrisse: Manuscritos Econômicos de 1857-1858. Esboços da Crítica da Economia Política. São Paulo: Boitempo Editorial.

Marx, Karl e Friedrich Engels. 2007. Manifesto Comunista. São Paulo: Boitempo Editorial.

Mattick, Paul. 1981. Economic Crisis and Crisis Theory. Londres: The Merlin Press. Disponível em: $<$ https:// libcom.org/files/Paul\%20Mattick\%20Economic\%20Crisis\%20and\%20Crisis\%20Theory.pdf $>$. Acesso em: 6 jun. 2016.

Mattick, Paul. 1983. Marxism: Last Refuge of the Bourgeoisie?. Nova Iorque: M.E. Sharpe Inc.

Mavroudeas, Stavros e Alexis Ioannides. 2011. "Duration, Intensity and Productivity of Labour and the Distinction between Absolute and Relative Surplus-value". Review of Political Economy, 23 (3): 421-437.

Ramtin, Ramin. 1991. Capitalism and Automation: Revolution in Technology and Capitalist Breakdown. Londres: Pluto Press.

Reuten, Geert. 2004. "Productive Force and the Degree of Intensity of Labour: Marx's Concepts and Formalizations in the Middle Part of Capital I". In The Constitution of Capital: Essays on Volume I of Marx's Capital, organizado por Nicola Taylor e Riccardo Bellofiore, 117-145. Houndmills: Palgrave Macmillan.

Roberts, Michael. 2016. The Long Depression: How it Happened, Why it Happened and What Happens Next. Chicago: Haymarket Books.

Rosdolsky, Roman. 2001. Gênese e estrutura de O Capital de Karl Marx. Rio de Janeiro: Contraponto Editora.

Savran, Sungur e E. Ahmet Tonak. 1999. "Productive and Unproductive Labour: An Attempt at Clarification and Classification". Capital \& Class, 68: 113-152.

Shortall, Felton. 1994. The Incomplete Marx. Aldershot: Avebury.

Silva Júnior, José Valdo Barros. 2010. "O Fetichismo: Para uma Crítica Radical do Trabalho Abstrato-Concreto. Investigações sobre a teoria do valor em Marx". Tese (Mestrado), Universidade Federal do Ceará, Fortaleza.

Smith, Tony. 2002. "Surplus Profits from Innovation - A missing level in Capital III?". In The Culmination of Capital: Essays on Volume III of Marx's Capital, organizado por Martha Campbell e Geert Reuten, 149-173. Houndmills: Palgrave Macmillan.

Sweezy, Paul. 1962. The Theory of Capitalist Development: Principles of Marxian Political Economy. Londres: Dennis Dobson Limited.

Thomas, Tom. 2004. La crise chronique ou le stade sénile du capitalisme. Bruxelas: Contradictions. 